\title{
LITTORAL DIATOMS FROM THE SALSTONE, NEAR PLYMOUTH
}

\author{
By F. Hustedt and A. A. Aleem \\ From the Hydrobiologische Anstalt der Max-Planck-Gesellschaft in Plön \\ and the Plymouth Laboratory
}

(Text-figs. I, 2)

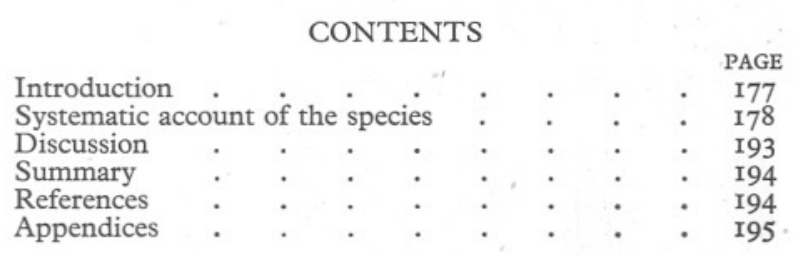

INTRODUCTION

The diatom flora inhabiting the muddy shores and bottoms off Plymouth has received little attention in comparison with the fauna associated with such muds. Since a large number of the microfauna depend, to a great extent, upon the diatoms as a source of food (Mare, I942), a knowledge of the latter is therefore desirable.

The present paper is mainly concerned with the diatoms inhabiting the mud-flats at the Salstone, a small island lying in the Salcombe estuary about one and a half miles above Salcombe. The habitat is of particular interest since it is sheltered from wave action, well defined, and hardly disturbed by man. Marine conditions prevail, the small fresh-water streams seeming to exert no appreciable influence on the salinity. Very few species of diatoms belonging to fresh water have been met with during the analysis of the present samples, and since these were in negligible quantities, they are excluded from the list given below.

The tidal range at the Salstone is of the order of $15 \mathrm{ft}$., but the islet itself lies well below M.H.w.s.; its uppermost parts being covered with Ascophyllum nodosum. The fucoids growing on this islet, as well as on the rocky shores facing it, display the usual zonation; a more detailed account of these will be dealt with separately by one of us (A.A.A.).

The diatoms considered below have been collected by the latter author during the months of February and March 1949, mainly from the mud-flats surrounding the islet, where a Vaucheria community covers large areas of the flats and extends to a level below M.L.w.s. The Vaucheria community harbours a large number of diatoms, some of which were found in abundance at the 
time of collection. The analysis of the samples has been carried out by us together at Plön.

Among the immense number of papers about diatoms, there are only very few specially dealing with the marine littoral vegetation. The most exhaustive one is written by Hustedt (I939) about the German coast of the North Sea. On British shores, Ghazzawi (1933) made a short study of the littoral diatoms of the Liverpool and Port Erin shores. He enumerates ninetyfour species and varieties, but ten of these species are fresh-water diatoms which do not really belong to the marine flora and therefore are not mentioned in our list. Of the remaining eighty-four species, forty-three were not found in our samples, or at least not recognized with certainty, though we are convinced that further studies in the Plymouth region will considerably increase the number of species upon our mud-flats.
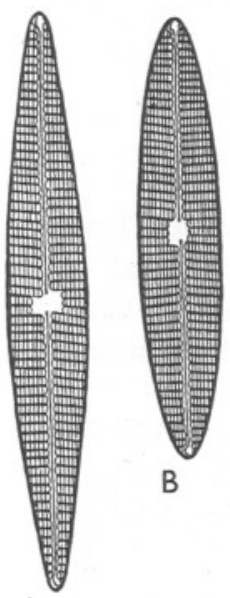

B
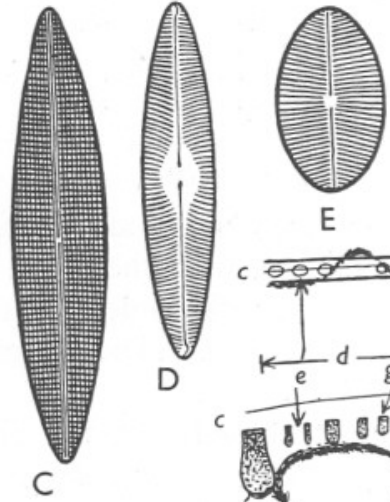

$\mathrm{E}$

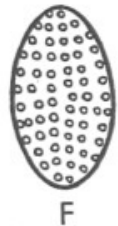

$F$

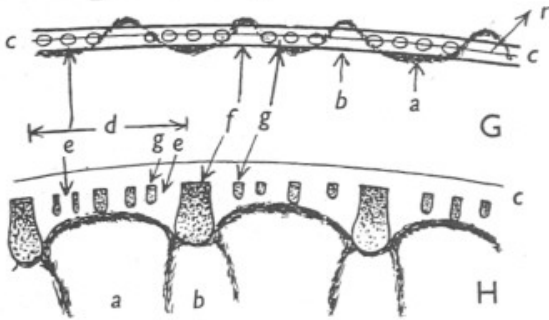

A

Fig. I. A, B, Navicula ramosissima Ag. $\times$ I200. C, N. britannica, n.sp. $\times$ I200. D, N. aleemi n.sp. $\times$ I200. E, F, Cocconeis guttata, n.sp. $\times$ I200. G, part of the ale of Surirella striatula Turp., top view. $\times$ I200. H, the same, seen from the inner side of the valve. $\times$ I200. $a$, crests; $b$, furrows; $c$, alar border canal; $d$, primary canal; $e$, secondary canals; $f$, primary windows; $g$, secondary windows; $r$, slit of the raphe. F.H. ad nat. del.

\section{Systematic Account of THE SPecies}

For the identification of the species the diatom material was boiled in acid in the usual way to get rid of the organic content of the cells, and subsequently thoroughly washed, the clean frustules being mounted in hyrax. The taxonomic arrangement followed is that of Hustedt (I930a).

\section{Genus Melosira Ag.}

Melosira moniliformis (Müll.) Ag. (Hustedt, I930b, p. 23I, fig. 95). Rather rare. The density of this species in certain localities on the southern coast of 
England shows considerable variation between the seasons as well as between different years (Aleem, I950 $b$ ).

M. Westii W.Sm. (Hustedt, I930b, p. 268, fig. II3). Rather frequent at M.T.L. and M.L.W.S. Occurs separately or in colonies of a few individuals. Longer chains were not met with.

M. sulcata (Ehr.) Kütz. (Hustedt, I930b, p. 276, fig. II9). Much more frequent than the other two species. It is a cosmopolitan diatom of general distribution, also known among the plankton as well as among littoral marine sediments, both recent and fossil.

\section{Genus Podosira Ehr.}

Podosira Montagnei Kütz. (Hustedt, I930b, p. 28I, fig. I22). Rare: a few valves were met with in samples from the Vaucheria community. This species is more common on rocky shores.

P. stelliger (Bail.) Mann (Hustedt, I930b, p. 286, fig. I28). This form grows attached to algae on rocky shores. Its presence on the mud-flats is probably due to sedimentation from the plankton.

Genus Hyalodiscus Ehr.

Hyalodiscus scoticus (Kütz.) Grun. (Hustedt, I930b, p. 293, fig. I33). Rare, probably also sedimented from plankton.

Genus Sceletonema Grev.

Sceletonema costatum (Grev.) Cleve (Hustedt, I930b, p. 3I I, fig. I49). Rare, sedimented from plankton.

\section{Genus Thalassiosira Cleve}

Thalassiosira decipiens (Grun.) Joerg. (Hustedt, I930b, p. 322, fig. I58). Rather rare; valves both of resting spores (thick-walled with coarse structure) and of vegetative cells (thinner walls) were found. Sedimented from plankton, more frequent in offshore waters near Plymouth in February-March.

\section{Genus Coscinodiscus Ehr.}

The species of Coscinodiscus found on the mud-flats at the Salstone are all planktonic.

C. excentricus Ehr. (Hustedt, I930b, p. 400, fig. 2II). Frequent. This species is widely distributed in all mud sediments on the north Atlantic coasts, especially in Germany and the Norwegian fjords.

C. radiatus Ehr. (Hustedt, I930b, p. 420, fig. 225). Rare.

C. centralis Ehr. (Hustedt, I930b, p. 444, fig. 243). Only fragments were found.

\section{Genus Roperia Grun.}

Roperia tessellata (Roper) Grun. (Hustedt, I930b, p. 523, fig. 297). Rare, deposited from plankton. 


\section{Genus Actinoptychus Ehr.}

Actinoptychus undulatus (Bail.) Ralfs (Hustedt, I930b, p. 475, fig. 264). Rather frequent. Only specimens of small size have, however, been encountered. The species is pelagic, though frequently met with in marine sediments.

Genus Eucampia Ehr.

Eucampia zoodiacus Ehr. (Hustedt, I930b, p. 772, fig. 45I). Only a few valves found. Planktonic.

\section{Genus Triceratium Ehr.}

Triceratium alternans Bail. (Hustedt, I930 b, p. 825, fig. 488). Rare, also found in colonies attached to the algae on rocky shores as well as being pelagic.

\section{Genus Biddulphia Gray}

Biddulphia aurita (Lyngb.) Bréb. \& God. (Hustedt, I930b, p. 846, fig. 50I). Rather rare at the Salstone. It was much more frequent on the mud-flats at Whitstable, Kent (Aleem, I950a). This species, which also occurs in a pelagic form, was produced in enormous quantities in the littoral region at Swanage, Dorset, during the spring of 1947 following a cold and rather long winter, while at the same period in the following year it was much less abundant (Aleem, I950b). Hustedt (I939) found this species in almost all samples collected from the mud-flats on the northern coasts of Germany. The species seems not to be endemic in the mud-flats but rather deposited there.

\section{Genus Rhabdonema Kütz.}

Rhabdonema minutum Kütz. (Hustedt, I93I, p. I8, fig. 548). Abundant in the Vaucheria community, less frequent on bare mud.

Rh. arcuatum (Lyngb.? Ag.) Kütz. (Hustedt, I93I, p. 20, fig. 549). Rather rare in the Vaucheria community.

\section{Genus Striatella Ag.}

Striatella unipunctata (Lyngb.) Ag. (Hustedt, I93 I, p. 32, fig. 560). Rather rare in the Vaucheria community.

\section{Genus Grammatophora Ehr.}

Grammatophora marina (Lyngb.) Kütz. (Hustedt, I93I, p. 43, fig. 569). Not infrequent among the Vaucheria community, rather rare on bare mud.

G. serpentina (Ralfs) Ehr. (Hustedt, I93I, p. 49, fig. 577). Very rare, found only among the Vaucheria community.

\section{Genus Licmophora Ag.}

The species belonging to this genus were more frequent in the Vaucheria community than on bare mud. The intercalary bands of the cells can be taken 
as a good character to distinguish the species. The septa in these bands are very short in Licmophora flabellata and L. Fuergensi, a little more distinct in L. gracilis and L. hyalina, while they are very deep in L. Ehrenbergi and L. paradoxa.

L. flabellata (Carm.) Ag. (Hustedt, I93I, p. 58, fig. 58I). Abundant, easily distinguished from the others by its four plate-like chromatophores.

L. gracilis (Ehr.) Grun. var. anglica (Kütz.) Peragallo (Hustedt, I93I, p. 60, fig. 583). Rather rare.

L. Fuergensi Ag. (Hustedt, I93I, p. 63, fig. 586). Rather common. Longitudinal and transverse striae of the valve are distinct.

L. Ehrenbergi (Kütz.) Grun. (Hustedt, I93I, p. 70, fig. 593). Rare, distinguished by its large size and coarse striae which are slightly radiate at the apex of the valve.

L. paradoxa (Lyngb.) Ag. (Hustedt, I93I, p. 76, fig. 605). Very common, especially in the Vaucheria community.

L. hyalina (Kütz.) Grun. (Hustedt, I93I, p. 8I, fig. 6II). Rather frequent. The shape of the valve resembles that of a tennis-racket with a short handle. The striae are dense (about 30 in Iо $\mu$ ), they are to be distinguished only on the lower part of the valve, while the upper part appears hyaline.

\section{Genus Dimerogramma Ralfs}

Dimerogramma minor (Greg.) Ralfs (Hustedt, I93I, p. II8, fig. 640). Not uncommon.

\section{Genus Opephora Petit}

Opephora marina (Greg.) Petit (Hustedt, I93I, p. I36, fig. 656). Not infrequent in the Vaucheria community.

\section{Genus Rhaphoneis Ehr.}

Rhaphoneis surirella (Ehr.) Grun. (Hustedt, I93I, p. I73, fig. 679a-c). Rather common. Widely distributed in all mud-flats.

R. amphiceros Ehr. (Hustedt, I93I, p. I74, fig. 680). Frequent, the valves in this species differ considerably both in size and shape.

\section{Genus Synedra Ehr.}

Synedra Gailloni (Bory) Ehr. (Hustedt, I93I, p. I95, fig. 690). Rather frequent.

S. tabulata (Ag.) Kütz. (Hustedt, I93I, p. 218, fig. 7Io $a-d$ ). Common. var. fasciculata (Kütz.) Grun. (Hustedt, I93I, fig. 710 $i-l$ ). Frequent. The cells in this variety tend to grow attached together in colonies like those of Fragilaria.

var. acuminata Grun. (Hustedt, I93I, p. 219, fig. 710e,f). Not infrequent, distinguished by its long, protracted, rostrate ends. 
Synedra crystallina (Ag.) Kütz. (Hustedt, I93I, p. 232, fig. 719). Rather rare.

S. investiens W.Sm. (Hustedt, I93I, p. 209, fig. 699). Rare.

Genus Thalassionema Grun.

Thalassionema nitzschioides Grun. (Hustedt, I93I, p. 244, fig. 725). Rare, sedimented from the plankton.

\section{Genus Thalassiothrix Cleve \& Grun.}

Thalassiothrix longissima Cleve \& Grun. (Hustedt, I93I, p. 247, fig. 726). Very rare. Deposited from plankton. The species is easily distinguished by its very long and narrow valves with spiny edges.

\section{Genus Campyloneis Grun.}

Campyloneis Grevillei (W.Sm.) Grun. (Hustedt, I93I, p. 32I, fig. 78I). Rare, more frequent on rocky shores, where it grows attached to algae such as Polysiphonia and Cladophora.

Genus Cocconeis Ehr.

Cocconeis scutellum Ehr. (Hustedt, I93I, p. 337, fig. 790). Very common, especially in the Vaucheria community.

var. stauroneiformis W.Sm. (Hustedt, I93I, p. 339, fig. 792). Frequent. The central area of the raphe-valve is enlarged into a narrow band reaching the margin.

C. dirupta Greg. (Hustedt, I931, p. 354, fig. 809). Not infrequent in the Vaucheria community.

C. pelta A. Schmidt (Hustedt, I93I, p. 36I, fig. 8I5). Rare. This species is similar to another species, namely C. peltoides Hustedt (I939, p. 606, figs. 23-27), which is more frequent in the mud-flats of the German coast. The latter, however, can be easily distinguished by the absence of a clear median area which is very distinct and punctate in C. pelta A.S.

C. guttata sp.nov. Valva elliptica, I $5 \mu$ longa, $9 \mu$ lata. Raphovalva raphi directa, area axiali angusta, area centrali parva, striis radiantibus, circiter 22 in го $\mu$. Areovalva area longitudinali angusta, granulata, granulis in lineis radialibus dispositis, circiter 9 in Io $\mu$ (Fig. I E, F).

Valves elliptical, length about I $5 \mu$, breadth about $9 \mu$. Raphe-valve with straight raphe, axial-area narrow, central-area rounded, very small, striae dense, about 22 in $10 \mu$, distinctly radiate, indistinctly punctate. Rapheless valve with rather narrow pseudoraphe, somewhat irregular, coarsely dotted; dots in slightly radiate rows, $8-9$ in $\mathrm{Io} \mu$.

C. guttata resembles $C$. distans Greg. in shape and structure of the valves. The striae in the former are much denser, however, being almost twice as dense. Besides, in $C$. distans the puncta are included in transapical costae 
which are slightly inflated round each punctum (Hustedt, I93 I, p. 344, fig. 797 . Peragallo, I897-I908, pl. 3, figs. I7, I8). Such costae do not exist in our species where the large dots are distinctly separated from each other. Nevertheless, further investigations may be required to decide whether these differences are constant.

C. guttata is very rare on the mud-flats at the Salstone. Type specimen preserved in the collection of Fr. Hustedt.

\section{Genus Achnanthes Bory.}

Achnanthes Lilljeborgei Grun. (Hustedt, I939, p. 609, figs. 39, 40). Very rare. The discovery of a single complete frustule of this characteristic species in our samples from the Salstone flats is very interesting since it sheds further light on our knowledge of this species. Length about $28 \mu$, breadth $8 \mu$, rapheless valve with faintly punctate costae, 9 in Io $\mu$. The raphe-valve is thinner, with

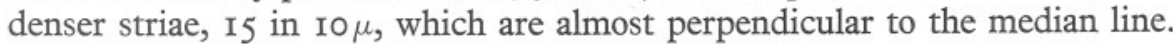
Raphe straight, axial area very narrow, no central area.

This is perhaps the second time in which the two real valves which belong to this species have been found together, the first was by Hustedt (I939) from the mud flats on the German coast. The specimens from these two localities are identical.

The rapheless valve of this species as figured by Cleve (1892, pl. 3, fig. I9) and Peragallo (I897-I908, pl. 2, fig. 5, right fig.!) is so characteristic that the specimen found by us undoubtedly belongs to this species. On the other hand, the valve with raphe which has been drawn both by Cleve (fig. 20) and by Peragallo (fig. 5, left fig.!) apparently do not belong to this species, as has been pointed out by Hustedt (I939), but rather to Navicula palpebralis f. Vahliana (Grun.) Hust., which seems to be generally distributed on mud-flats in the European north Atlantic coasts. The statement by Cleve (I895) that the axial area of the lower (=raphe-) valve of Achnanthes Lilljeborgei is 'lanceolate narrow' applies more to this Navicula.

There can be no doubt that the raphe-valve which we found attached to the rapheless valve in our material is the true valve of this Achnanthes.

A. Hauckiana Grun. (Hustedt, I93I, p. 388, fig. 834). Rare. Brackish water species of general distribution on European coasts.

A. brevipes Ag. (Hustedt, I93I, p. 424, fig. $877 a-c$ ). Only a few valves were met with in the sediment.

var. parvula (Kütz.) Cleve (Hustedt, I93I, p. 426, fig. $877 f-i$ ). Rare. Both the species and its variety are more common on rocky shores in the spray zone (Aleem, 1950 $b$ ).

A. longipes Ag. (Hustedt, I93I, p. 427, fig. 878). Very common in the Vaucheria community in the lower littoral region. The zonal distribution of this species at the Salstone is similar to that described by Aleem (I950 $b$ ) from other localities. 


\section{Genus Diploneis Ehr.}

Diploneis bombus Ehr. (Hustedt, I931, p. 704, fig. I086). Rather rare.

D. aestuari Hustedt, (Hustedt, I939, p. 6I2, figs. 4I, 42). Rather frequent, first known from the German coast. Valve elliptical, slightly constricted, length about $\mathrm{I}_{5} \mu$, breadth about $6 \mu$, transapical striae about I8 in Io $\mu$.

Genus Amphipleura Kütz.

Amphipleura rutilans (Trent.) Cleve (Hustedt, I93I, p. 720, fig. I093 $a, b$ ). Frequent, filaments were found growing on the mud at M.T.L.

\section{Genus Stauroneis Ehr.}

Stauroneis salina W. Smith (Hustedt, I930a, p. 258, fig. 4I4). Frequent, the species has a wide distribution in the mud-flats.

\section{Genus Navicula Bory.}

Since only a comparatively small number of species of this very large genus were found, we prefer to give them here in alphabetical order.

Navicula abrupta Greg. (Cleve, I895, p. 6I, A.S. Atl. pl. 3, figs. I, 2). Frequent, some of the specimens found are smaller than is cited in the literature. The smallest valves found are about $30 \mu$ long and $17 \mu$ broad.

$N$. aleemi Hustedt, sp.nov. Valva lineari-lanceolata, apicibus subobtusis, non protractis, circiter $26 \mu$ longa et $6 \mu$ lata. Raphe directa, area axiali angusta, in media parte valvarum lanceolate amplificata, area centrali modice lata. Striis in media parte valvarum leniter radiantibus, $20-24$ in $10 \mu$, ad polos leniter convergentibus, densioribus, circiter 30 in $\mathrm{Io} \mu$ (Fig. I D).

Valve linear-lanceolate with slightly convex margins and rather obtusely rounded ends, about $26 \mu$ long and $6 \mu$ broad. Raphe straight, embedded in a distinct longitudinal median rib. Axial area narrow, towards the central nodule lanceolately enlarged. Central area moderately large, elliptical lanceolate. Striae slightly radiate, at the ends of the valve slightly convergent, round the central area $20-24$ in Io $\mu$, becoming denser towards the ends, till 30 in $\mathrm{Io} \mu$. Longitudinal lines inconspicuous.

This species belongs to the group of the Naviculae lineolatae, but is distinguished from the other species by its distinct longitudinal median rib, the shape of the areas and by its dense structure.

Rare, found on the mud flats at the Salstone, type specimen in the collection of Fr. Hustedt.

N. arenaria Donk. (Donkin, I87I-2, p. 56, pl. 8, fig. 5). Not rare. More frequent on sandy flats (Hustedt, I939, p. 622).

N. avenacea (Bréb.) (Cleve, I895, p. I5). Rare, only a few valves belonging to this species have been found.

$N$. britannica sp.nov. Valva lineari-lanceolata, apicibus acutis, circiter $39 \mu$ longa et $8 \mu$ lata. Raphe directa, poris centralibus approximatis, area axiali 
angustissima, area centrali nulla. Striis transapicalibus fere perpendicularibus vel leniter radiantibus, circiter 20 in $\mathrm{Io} \mu$, striis longitudinalibus directis, circiter 24 in $10 \mu$ (Fig. I C).

Valves linear-lanceolate with convex margins and acute ends, $39 \mu$ long and $8 \mu$ broad. Raphe straight, with very approximate central pores, axial area very narrow, no central areas. Striae perpendicular to the median line or very slightly radiate, about 20 in Io $\mu$, crossed by distinct straight longitudinal lines, about 24 in Io $\mu$.

This species also belongs to the Naviculae lineolatae, especially to the group of N. ramosissima Ag. and its allied forms. It is distinguished by its very approximate central pores and its denser structure.

Found on the mud-flats of Salstone, but rare. Type specimen in the collection of Fr. Hustedt. The species was also found previously by one of us (A.A.A.) at Swanage.

$N$. cancellata Donk. (Cleve, I895, p. 30). Frequent, easily recognized by its strong and distinctly lined ribs and slightly constricted frustules in girdle view.

N. crucigera (W. Smith) Cleve (Hustedt, I930a, p. 270, fig. 439). Frequent.

$N$. cryptocephala Kütz. (Aleem, I949, p. 436, fig. $8 a, b$ ). Frequent, widely distributed in mud-flats.

var. veneta Kütz. (Aleem, I949, fig. $8 c, d$ ). Frequent.

N. digitoradiata (Greg.) A. Schmidt (Hustedt, I930a, p. 30I, fig. 518). Frequent.

N. flanatica Grun. (Hustedt, I939, p. 628, figs. 86-90). Rather frequent, distinguished by its distinct lanceolate axial area and by its coarse longitudinal lines.

N. forcipata Grev. (Cleve, I895, p. 65). Frequent.

var. densestriata A. Schmidt, (p. 66). Rather frequent, valves 50-60 $\mu$ long, $\mathrm{I} 5 \mu$ broad, striae 22 in $\mathrm{IO} \mu$.

N. gregaria Donk. (Hustedt, I930a, p. 269, fig. 437). Frequent, distinguished from $N$. cryptocephala mainly by its less radiate striae and the presence of clear longitudinal lines.

N. (Schizonema) grevillei Ag. (Cleve, I894, p. I52). Rare.

N. groschopfi Hustedt (Hustedt, I939, p. 63I, figs. I02, I03). Frequent, first described by Hustedt from mud-flats on the German coast. The species is characterized by its small size and dense striae $(20$ in Io $\mu)$ and rhombiclanceolate valves.

N. lyra Ehr. (Cleve, I895, p. 63). Rare, widely distributed on mud-flats. Most of our specimens belong to var. intermedia Peragallo (I897-I908, pl. 23, figs. 6-IO), which we have not separated.

N. ostrearia Turp. (Peragallo, I897-I908, pl. 7, fig. 22). Common. This Navicula is easily distinguished in the living state by its blue colour and hyaline structure. It grows associated with mussels and shells in the Fucus zone. 
N. palpebralis Bréb. f. Vahliana (Grun.) (Hustedt, I939, p. 635. Schmidt, I874, pl. 2, fig. 2I). Rather frequent, widely distributed on mud-flats.

N. plicata Donk. (Cleve, I894, p. I54). Not frequent. The valves in this species are in most cases linear-lanceolate with more or less convex margins, but not linear alone as described by Cleve, and Peragallo (I897-I908, pl. 8, fig. I5). Besides, the striae are more radial than is shown in Peragallo's figure.

N. (Schizonema) ramosissima Ag. (Cleve, 1894, p. 26). Frequent. (Fig. I A, B).

var. mollis (W. Smith) (Aleem, 1949, p. 432, fig. 6f, g). Frequent.

N. salinicola Hustedt (Hustedt, 1939, p. 638, figs. 6I-69). Frequent.

\section{Genus Pinnularia Ehr.}

Pinnularia ambigua Cleve (Cleve, I895, p. 94). Rare. As Hustedt (I939, p. 64I) has already pointed out, this species should perhaps be transferred into the genus Amphora. The frustules are distinguished by a rather larger number of intercalary bands and are mostly asymmetrical to the apical plane as in the species of the genus Amphora. The valves are not always symmetrical to the apical axis, but more or less asymmetrical. We leave this species at present in Pinnularia until further studies of these two genera are undertaken.

\section{Genus Trachyneis Cleve}

Trachyneis aspera (Ehr.) (Cleve, I894, p. I9I). Rare, also known from other mud-flats of the European coasts.

Genus Scoliopleura Grun.

Scoliopleura tumida (Bréb.) Rabh. (Heiden in Schmidt (1874-I944), pl. 262, figs. I-4, 6). Frequent.

\section{Genus Scoliotropis Cleve}

Scoliotropis latestriata (Bréb.) Cleve (Heiden in Schmidt (I874-I944), pl. 26I, figs. 4, 5). Rather frequent.

\section{Genus Caloneis Cleve}

Caloneis liber (W. Smith) (Cleve, I894, p. 54). Rare.

\section{Genus Gyrosigma Hass.}

Gyrosigma balticum (Ehr.) Rabh. (Hustedt, I930a, p. 224, fig. 33I). Not infrequent, easily distinguished by its more or less long linear valves and distinct striae.

G. Spenceri (W. Smith) Cleve (Hustedt, I930a, p. 225, fig. 336). Rather frequent.

G. fasciola (Ehr.) (Cleve, I894, p. II6). Frequent, characterized by its long protracted ends. 


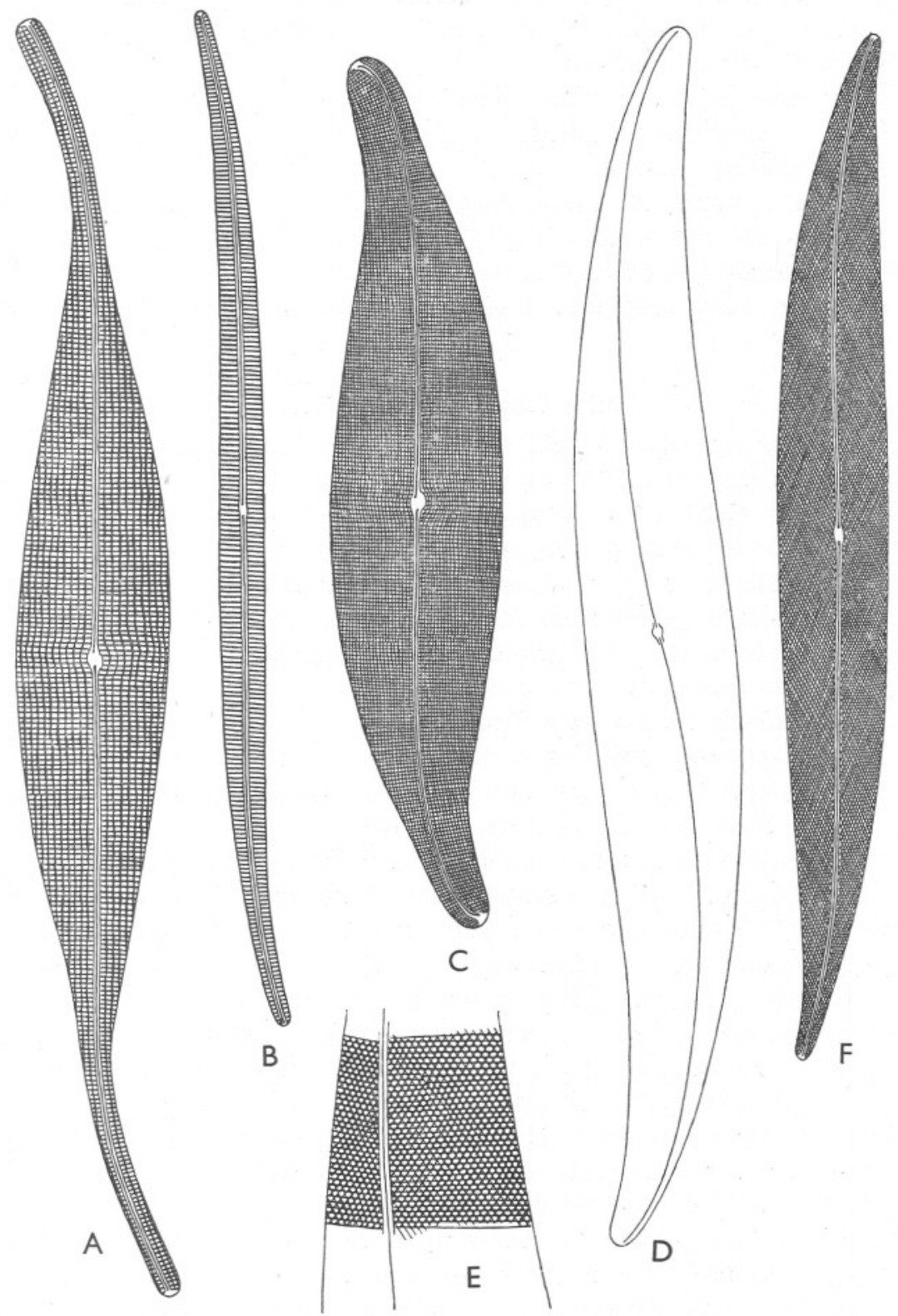

Fig. 2. A, Gyrosigma fasciola var. sulcata Grun. $\times$ I200. $\quad$ B, G. tenuissimum (W. Smith) Cleve. $\times$ I200. C, G. distortum (W. Smith) Cleve. $\times$ i200. D, Pleurosigma maroccanum Cleve. $\times 600$. E, part of same. $\times$ I200. F, P. subhyalinum Hust. \& Al, n.sp. $\times$ I200. F.H. ad nat. del. 
var. sulcata Grun. (Cleve, I894. Van Heurck, I880-5, pl. 2I, fig. 7). More frequent than the typical form, from which it is distinguished by the stronger longitudinal striae (Fig. 2A).

G. distortum (W: Smith) Cleve (Hustedt, I930a, p. 224, fig. 334). Not rare. The ends of the valves found are less protracted and more obtuse than described in the literature. (Fig. $2 \mathrm{C}$ ).

G. littorale (W. Smith) (Cleve, I894, p. II6). Rather rare. A very characteristic species, distinguished especially by the distant longitudinal lines.

G. tenuissimum (W. Smith) (Cleve, I894, p. II7). Rather rare. Transapical striae 20 in Iо $\mu$, longitudinal ones much denser, scarcely to be seen. (Fig. 2B).

\section{Genus Pleurosigma W. Smith}

Pleurosigma angulatum (Quek.) W. Smith (Cleve, I894, p. 40). Rare.

P. aestuari Bréb. (Cleve, I894, p. 42). Frequent.

P. Normani Ralfs (Cleve, I894, p. 40). Rather rare.

$P$. naviculaceum Bréb. (Cleve, I894, p. 36). Rather frequent. The structure is coarser in the middle part of the valves, becoming denser towards the ends. In this respect it agrees with $P$. Normani and it seems that $P$. Normani comprises only the larger specimens of $P$. naviculaceum. In this paper we leave the two species separate until Hustedt's studies of the genus for the publication in the Kieselalgen are finished.

$P$. subhyalinum sp.nov. Valva sigmoidea, apicibus acutis, circiter $105 \mu$ longa, II $\mu$ lata. Raphe sigmoidea centrali, area axiali nulla, area centrali parvissima. Structura delicatissima, striis obliquis $32-36$ in $10 \mu$, sub angulo $45-50^{\circ}$ decussatis, striis transapicalibus inconspicuis, $28-30$ in $10 \mu$. (Fig. 2F).

Valves slender, hyaline, sigmoid with acute ends, length about $105 \mu$, breadth II $\mu$. Raphe sigmoid, central, axial area absent, central area very small. Structure very delicate, only to be resolved in a medium with high refractive index, oblique striae $32-36$ in ro $\mu$, crossing each other with an angle of $45-50^{\circ}$. Transapical striae inconspicuous, $28-30$ in IO $\mu$.

The structure of the valve in this species is perhaps akin to $P$. hyalinum Grun. (Cleve \& Grunow, I880, p. 52), later cited by Cleve (1894, p. 42) in a note with $P$. javanicum Grun. However, neither Grunow nor Cleve has given any figure of this species and concerning the number of striae they state only that these are 'too delicate for measuring'.

It has been the experience, however, in dealing with the species belonging to Pleurosigma to take into consideration two important characters, namely: the exact shape of the valve with its raphe, and the number of striae. But since neither of these conditions has been satisfied in P. hyalinum Grun., we find ourselves unable to refer our specimen to this species and we prefer to keep it separate.

P. obscurum W. Smith (Cleve, I894, p. 43). Rather rare. 
P. formosum W. Smith (Cleve, I894, p. 45). Not rare, but mostly in fragments.

P. (Rhoicosigma?) maroccanum Cleve (Cleve, I894, p. 42). (Rhoicosigma maroccanum Cleve in Peragallo, I893, p. 32, pl. 9, fig. 22). Very rare. Cleve considers this a doubtful species, requiring further examination. There exists only one figure of it made by Peragallo, which was copied by the same author (I897-I908, pl. 36, fig. I). For these reasons and because of the fact that we found only a single valve in our samples which we are sure belongs to this species, we prefer to give a figure and a short description of our specimen.

Valve distinctly sigmoid with rather acute ends, length $250 \mu$, breadth $30 \mu$ ! Raphe more sigmoid than the valve (therefore strongly excentric towards the ends!). Oblique striae about $\mathrm{I} 7$ in $\mathrm{IO} \mu$, transapical striae about $\mathrm{I} 9$ in $10 \mu$. Central area very small (Fig. 2D, E).

The valve is slightly bent in the transapical axis as in species belonging to the genus Rhoicosigma. On the other hand, in this latter subgenus, unlike Pleurosigma, the two valves are different in shape. Since the second valve in P. maroccanum seems not to be known (at least not mentioned in the literature), it is doubtful whether the two valves belonging to the same frustule of $P$. maroccanum differ at all.

\section{Genus Amphiprora Ehr.}

Amphiprora paludosa W. Smith (Hustedt, I930a, p. 339, fig. 624). Rather frequent.

A. pulchra var. pulchella (Peragallo, I897-1908, pl. 37, figs. 4, 5). Rare.

A. sulcata O'Meara (Peragallo, 1897-I908, pl. 38, figs. I-3). Rather rare.

\section{Genus Tropidoneis Cleve}

Tropidoneis Vanheurcki Grun. (Peragallo, I897-I908, pl. 40, figs. I2, I3). Frequent.

T. vitrea W. Smith (Peragallo, I897-I908, pl. 4I, figs. 7, 8). Frequent. The last two species are generally distributed in mud-flats.

\section{Genus Auricula Castr.}

Auricula dubia Peragallo (Peragallo, I897-I908, pl. 42, figs. 8-II). Only a single specimen found.

\section{Genus Amphora Ehr.}

\section{Subgenus Amphora Cleve}

Amphora proteus Greg. (Cleve, I895, p. I03). Frequent, widely distributed in all marine coasts.

A. marina (W. Smith) Van Heurck (Cleve, I895, p. I03). Rather frequent, this species is similar to the previous one, with which it may be united. 


\section{Subgenus Halamphora Cleve}

Amphora coffaeiformis Ag. (Hustedt, I930a, p. 345, fig. 634). Very common. Also common on other mud-flats as well as on the rocky shore. The species is very variable. Many small species of Amphora have been described which probably belong to this species.

var. acutiuscula (Kütz.) (Hustedt, I930a, p. 346). Rather frequent. Structure coarser than in the species. Both the species and its variety are of wide distribution both in marine coast lines and in salt lakes and ponds. They are able to stand a rather wide variation of $\mathrm{pH}$.

A. costata W. Smith (Cleve, I895, p. I22). Rare.

A. turgida Greg. (Cleve, I895, p. I23). Rare.

Subgenus Oxyamphora Cleve

Amphora lineolata Ehr. (Hustedt, I930a, p. 346, fig. 636). Frequent.

A. hyalina Kütz. (Cleve, I895, p. I27). Very rare, distinguished by its semicircular valve in girdle view, structure hyaline.

$A$. arcus Greg. (Cleve, I895, p. 127). Not rare.

A. ostrearia Bréb. (Cleve, I895, p. I29). Common. Similar to A. arcus, but distinguished by its narrow stauros.

A. laevis var. laevissima Greg. (Cleve, I895, p. 130). Rare.

Subgenus Psammamphora Cleve

Amphora ocellata Donk. (Cleve, I895, p. I33). Rare.

Subgenus Cymbamphora Cleve

Amphora angusta (Greg.) (Cleve, I895, p. I35). Rather frequent.

Genus Gomphonema Ag.

Gomphonema exiguum Kütz. (Cleve, I894, p. I88). Rare.

Genus Rhopalodia O. Müller

Rhopalodia musculus (Kütz.) O. Müll. (Hustedt, I930a, p. 392, fig. 745). Not rare, but more common in brackish water.

\section{Genus Cylindrotheca Rabh.}

Cylindrotheca gracilis (Bréb.) Grun. (Hustedt, I930a, p. 393, fig. 746). Rather frequent, this species could easily be overlooked because of its hyaline structure. It belongs to the Nitzschiaceae and is characterized by its spirally twisted keels.

Tryblionellae

Genus Nitzschia Hass.

Nitzschia punctata (W. Smith) Grun. (Van Heurck, I880-5, pl. 57, figs. I9, 20). Frequent.

var. coarctata Grun. (Hustedt in Schmidt, I874-I944, pl. 330, fig. I6). Frequent. 
N. acuminata (W. Smith) Grun. (Hustedt, I930a, p. 40I, fig. 764). Rather frequent.

N. apiculata (Greg.) Grun. (Hustedt, I930a, p. 40I, fig. 765). Frequent.

\section{Dubiae}

Nitzschia commutata Grun. (Hustedt, I930a, p. 405, fig. 774). Rare.

N. littorea Grun. (Van Heurck, I880-5, pl. 59, fig. 2I). Rather rare, found only in the Vaucheria community. Characterized by the very distant median keel-puncta.

N. dubiiformis Hustedt (Hustedt, I939, p. 658, figs. III-II3). Very common in the mud-flats. First described from the German coast, where it is also very frequent, especially on the sandy flats. It is characterized by its hyaline valves, dense striae and by its very variable number of keel-puncta which vary from Io to I 8 in Io $\mu$, the two median ones are more distant than the others.

\section{Panduriformes}

Nitzschia panduriformis Greg. (Hustedt in A.S. Atl. pl. 33I, figs. I9-2I). Rather rare. Much more frequent on warmer coasts.

N. constricta (Greg.) Grun. (Van Heurck, I880-5, pl. 58, fig. 8). Rather common.

\section{Lanceolatae}

Nitzschia aequorea Hustedt (Hustedt, I939, p. 663, fig. I20). Rather rare, characterized by its typical lanceolate valves, acute ends, small size and dense striae, which are about 35 in $10 \mu$.

\section{Sigmoideae}

Nitzschia sigma (Kütz.) W. Smith (Hustedt, I930a, p. 420, fig. 813). Common.

\section{Spathulatae}

Nitzschia angularis W. Smith (Van Heurck, I880-5, pl. 62, figs. II-I4). Not infrequent.

N. distans Greg. (Peragallo, I897-1908, pl. 73, fig. 3). Common.

\section{Dissipatae}

Nitzschia macilenta Greg. (Peragallo, I897-I908, pl. 72, figs. I, 2). Rare.

N. socialis Greg. (Peragallo, I897-I908, pl. 72, figs. 7, 8). Rather frequent.

\section{Pseudonitzschiae}

Nitzschia pungens Grun. (Cleve \& Möller, I882, Diat. No. 307, Cleve, I897, p. 24, pl. 2, fig. 23). Rare. This species has hitherto been only known from Japan, and apart from the above two references there is no other mention of it in the literature. Cleve describes a variety atlantica from the Kattegat 
with somewhat denser striae ( 15 in Io $\mu$ ), but our specimens agree more with the species than with this variety (length $\operatorname{Io0} \mu$, breadth $4.5-5 \mu$, striae about Io in $10 \mu$ ).

The species is akin to Pseudonitzschia sicula Castr., P. migrans Cleve and P. seriata Cleve figured in Peragallo (I897-I908, pl. 72, figs. 25-29) under the group Pseudonitzschia. The constriction of cell is not yet exactly known in this group, in which no keel-puncta are to be seen and that is perhaps the reason why some of the species included have been referred to Synedra.

Further studies are required in order to show the taxonomic position of this group and to elucidate the relation between the different species and until this is done we retain the original nomenclature of Grunow.

\section{Nitzschiellae}

Nitzschia closterium (Ehr.) W. Smith (Hustedt, I930a, p. 424, fig. 822). Very common. Also widely known in the plankton. It was rather common in the plankton off Plymouth in March.

N. longissima (Bréb.) Ralfs (Schmidt, 1874-1944, pl. 335, figs. I, 2). Not infrequent on the mud-flats.

\section{Genus Surirella Turp.}

Surirella ovalis Bréb. (Hustedt, I930a, p. 44I, figs. 860, 86I). Rare.

S. gemma Ehr. (Van Heurck, I880-5, pl. 74, figs. I-3). Frequent.

S. fastuosa Ehr. (Peragallo I897-I908, pl. 58, figs. 5-7). Rather rare.

S. caspia Brun (Brun, I89I, p. 45, pl. I3, fig. 6). S. cardaria Brockmann (Brockmann, I9I4, p. 70, fig. II). Rare; only in the Vaucheria community.

This is an interesting species of which little is known. Apart from the figure given by Brun, his description of this species is quite insufficient. The only other mention, according to our knowledge, is a record by Meister (I932, p. 24) among a list of diatoms from the mouth of Belawan river in Sumatra. In the collection of Hustedt is to be found the original material of Surirella caspia Brun from the Caspian Sea, as well as that of $S$. cardaria Brockmann from the mouth of the Weser. These two species are identical, and we quote Brockmann's species as a synonym of $S$. caspia Brun and give the following description of the latter:

Cells with heteropolar apical axis, slightly twisted round this axis. Valves more or less broadly ovate to nearly orbicular, with obtusely rounded ends, 50-120 $\mu$ long, 36-60 $\mu$ broad. Ales broad, with distinct projection, primary alar canals broader than the windows, IO-20 in $100 \mu$. Below the alar bordercanal (see Appendices I and II), the primary alar canals are divided by short ribs into two to five secondary alar canals. Surface of the valve distinctly undulated. The crests of these undulations end on the ales in broad and flatly rounded arcs, while towards the median line the furrows are broader than the crests. Median area more or less developed, though not sharply defined. Transapical striae coarse, about I 2 in Io $\mu$ near the border of the valve. Short spines are scattered all over the surface of the valve, specially on the crests. 


\section{Genus Campylodiscus Ehr.}

Campylodiscus Thureti Bréb. (Peragallo, I897-I908, pl. 57, figs. 8, 9). Very rare, only one specimen was found in the Vaucheria community. More frequent on warmer coasts.

\section{Discussion}

The species recorded in this paper are similar to those inhabiting mud-flats at Whitstable, Kent (Aleem, I949). Many are also recorded by Hustedt (I939) from mud-flats on the German coast. Such marine mud-flats are, as a rule, rich in species belonging to the Raphidae, particularly those of the genera Amphora, Gyrosigma, Navicula, Nitzschia, Pleurosigma and Tropidoneis. These possess a well-developed raphe and are capable of moving freely within the substratum (Aleem, I950 a). They are to be found on the flats all the year round, though in varying degrees of abundance in the different seasons.

The mud-flats also comprise, in less significant quantities, other species which are recruited from three different sources, namely: (i) attached forms from the rocky shore, (ii) pelagic forms from the plankton, (iii) fresh-water forms from rivers and lakes. The last of these is much less significant than the others. Among those recruited from the rocky shore and found on the flats at the Salstone are species of Cocconeis, Achnanthes, Licmophora, Grammatophora and Rhabdonema. They are mostly colonial forms which grow attached by gelatinous stalks to rocks or as epiphytes on algae. Such forms were represented on the bare mud by only a few detached individuals, owing to lack of a proper substratum. A number of them, however, were much more frequent as epiphytes on seaweeds, especially in the Vaucheria community at M.L.W.S. The following diatoms are the principal species recognized from this community during the period of collection:

$\begin{array}{ll}\text { Achnanthes longipes } & \text { L. flabellata } \\ \text { Amphora coffaeiformis } & \text { L. Fuergensi } \\ \text { A. hyalina } & \text { Opephora marina } \\ \text { Cocconeis scutellum } & \text { Synedra Gailloni } \\ \text { Grammatophora marina } & \text { S. tabulata } \\ \text { Licmophora gracilis var. anglica } & \end{array}$

Among those recruited from the plankton and to which reference has been made in this paper are the following species:
Actinoptychus undulatus
Coscinodiscus centralis
C. excentricus
C. radiatus
Eucampia zoodiacus
Hyalodiscus scoticus

Nitzschia pungens

Roperia tessellata

Sceletonema costatum

Thalassionema nitzschioides

Thalassiosira decipiens

Thalassiothrix longissima 
They are mostly centric forms, rare on the mud-flats, and their presence here accidental. Most of them are more frequent in the plankton off Plymouth during March. No species of the genera Chaetoceros or Rhizosolenia were met with, neither as vegetative cells nor as resting spores, in our samples from the mud-flats, although these two genera were richly represented in the Plymouth plankton.

Apart from these, there are species which thrive equally well both in the plankton and in the littoral region. A conspicuous example of these is Nitzschia closterium which is found in appreciable quantities on all mud-flats, in littoral and supra-littoral pools as well as among the plankton. It is also known as a bottom form able to live in less well-oxygenated conditions (Mare, I942). Melosira moniliformis, M. sulcata and Biddulphia aurita are also examples which are equally abundant both in the littoral region and in the plankton. It is more probable, however, that the origin of such species is in the littoral region and that later on they are recruited into the plankton, where they still retain the capacity to multiply.

\section{SUMMARY}

A systematic study of the marine diatoms inhabiting the mud-flats at the Salstone, South Devon, is given. Altogether $\mathrm{I}_{32}$ species and 9 varieties, belonging to 45 genera are mentioned. Among these the following are described as new species: Cocconeis guttata, Navicula aleemi Hust., N. britannica, Pleurosigma subhyalinum.

Four other little-known diatoms, namely, Achnanthes lilljeborgei, Nitzschia pungens, Pleurosigma maroccanum and Surirella caspia, have also been found in the same locality and a detailed description of these is given. The Salstone diatoms are in essential respects similar to those found in other European north Atlantic mud-flats.

\section{REFERENCES}

AleEM, A. A., 1949. Distribution and ecology of marine littoral diatoms. Consideration of the littoral diatom-flora with special reference to forms living in gelatinous tubes. Bot. Notiser, Lund, 1949, pp. 517-54.

- I950 $a$. The diatom community inhabiting the mud-flats at Whitstable, Kent. New Phytol., Vol. 49, pp. 174-88.

- $1950 \mathrm{~b}$. Distribution and ecology of British marine littoral diatoms. Fourn. Ecol., Vol. 38, pp. 75-106.

Brockmann, Chr., I9I4. Brackwasserstudien. Ver. Naturk. Unterweser, Bd. Iv. Geestemünde.

Brun, J., I89r. Diatomées espèces nouvelles. Mém. Soc. Phys. et Hist. Nat. Genève, Vol. xxxI, pt. II, pp. I-48.

Cleve, P. T., I892. Sur quelques espèces nouvelles ou peu connues. Diatomiste, Vol. II, p. 143 . 
Cleve, P, T., I894. Synopsis of the naviculoid diatoms. I. K. Svenska Vetensk. Akad. Handl., Bd. 26, no. 2.

- I895. Synopsis of the naviculoid diatoms. II. K. Svenska Vetensk. Akad. Handl., Bd. 27 , no. 3 .

- 1897. A treatise on the phytoplankton of the Atlantic and its tributaries. Uppsala.

Cleve, P. T. \& A. Grunow, I880. Beiträge zur Kenntnis der arktischen Diatomeen. K. Svenska Vetensk. Akad. Handl., Bd. I7, no. 2.

Cleve, P. T. \& Möller, J. D. I882. Diatoms, pt. vi. Uppsala.

DonkIn, A. S., I871-2. British Diatomaceae. London.

GhazzaWI, F. M., I933. The littoral diatoms of the Liverpool and Port Erin shores. fourn. Mar. Biol. Assoc., Vol. xIx, pp. 165-76.

Hustedt, Fr., I930a. Bacillariophyta, in A. Pascher, Süsswasserflora Mitteleuropas. Bd. ro. Jena.

— I930b. Die Kieselalgen Deutschlands, Österreichs und der Schweiz mit Berücksichtigung der übrigen Länder Europas sowie der angrenzenden Meeresgebiete, in L. Rabenhorst's Kryptog.-Flora, Vol. viI, pt. I.

— I 93 I ff. Die Kieselalgen, in L. Rabenhorst's Kryptog.-Flora, vol. viI, pt. 2.

— I939. Die Diatomeenflora des Küstengebietes der Nordsee vom Dollart bis zur Elbemündung. I. Die Diatomeenflora in den Sedimenten der unteren Ems sowie auf den Watten in der Leybucht, des Memmert und bei der Insel Juist. Abh. Nat. Ver. Bremen, Vol. xxxI, pp. 572-677.

LAUTERBoRn, R., 1896. Untersuchungen über Bau, Kernteilung und Bewegung der Diatomeen. Leipzig.

MARE, M. F., I942. A study of a marine benthic community with special reference to the microorganisms. Fourn. Mar. Biol. Assoc., Vol. xxv, pp. 517-54.

MeIster, Fr., I932. Kieselalgen aus Asien. Berlin.

MÜLLER, O., I903. Bacillariaceen aus dem Nyassalande und einigen benachbarten Gebieten. I. Surirelloideae-Surirelleae. Engl. Bot. Fahrb., Bd. xxxiv.

Peragallo, H., I893. Monographie du genre Pleurosigma. Diatomiste, Vol. I. Paris.

— I897-1908. Diatomées marines de France et des districts maritimes voisins. Grez sur-Loing.

Schmid, A., I874. Die in den Grundproben der Nordseefahrt vom 21. Juli bis 9. September 1872 enthaltenen Diatomaceen. Fahresber. Komm. Unters. deutsch. Meere in Kiel, Bd. II.

—- I874-1944. Atlas der Diatomaceenkunde, fortgesetzt von M. Schmidt, Fr. Fricke, O. Müller, H. Heiden und Fr. Hustedt. Aschersleben und Leipzig.

VAN Heurck, H., I880-5. Synopsis des diatomées de Belgique. Anvers.

\section{APPENDIX I}

It has become necessary with the advance of our knowledge of diatoms due to modern microscopy to introduce some new terms describing certain configurations in the structure of the valve. Some such terms have already been proposed in the German literature by R. Lauterborn, O. Müller and Fr. Hustedt for which no equivalent translations have yet been given. We therefore propose the following translations of such German terms as we have used in this respect in our paper.

'Raphenschale' (sensu Hustedt, I930a, p. I88)= raphe-valve. 
'raphenlose Schale' (sensu Hustedt, I930a, p. I88)= rapheless valve.

'Flügelrandkanal' (sensu Lauterborn, I896, p. I5=Querkanal)=alar border canal.

'Fenster' (sensu O. Müller, 1903, p. 24)=windows (for the intervening spaces between the alar canals of Surirella, also equivalent to the keel puncta in Nitzschia).

'Wellenberge' (sensu Lauterborn, I896, pp. I4, I5)=crests.

'Wellentäler' (sensu Lauterborn, I896, pp. I4, I5) = furrows.

The last two terms describe the undulations of the valve of Surirella. The word 'crest' had already been adopted by others, while 'Wellentäler' was formerly translated by 'hollows'. We prefer the term 'furrows' which seems to be more appropriate for the structure in question, and we suggest that the word 'depressions' might better be applied to the space between the median line and margin (in the valve of Surirella) in apical direction.

'Schleifenköpfe' (sensu O. Müller, I903, p. 25)=arcs.

'Primärkanäle' = primary canals (see appendix II).

'Sekundärkanäle' = secondary canals (see appendix II).

'sekundäre Fenster' = secondary windows (see appendix II).

\section{APPENDIX II}

Additional note on the construction of the ales in Surirella

By Fr. Hustedt

Lauterborn (I896, pp. I4-I6, pl. I, figs. 8-I2) made an intensive study of the structure of the ales in Surirella calcarata Pfitz. Most other species of this genus, specially the fresh-water forms, have ales identical with those of the latter species. Since many marine species of the genus deviate from it in structure, it is necessary to give here some additional remarks.

In many species the crests on the surface of the valve are very enlarged towards the basis of the ales, so that the alar canals become very broad too. In such cases narrow ribs or small windows project from the inner wall of the border canal into these enlarged alar canals in varying degrees, thus dividing the mouth of the alar canals into more or less numerous small openings. I have called the original alar canals 'primary canals', the smaller ones inside the latter 'secondary canals', and the spaces left between two adjacent canals 'secondary windows'. 